\title{
УСЛОВИЯ ОТБЫВАНИЯ НАКАЗАНИЯ БЕРЕМЕННЫМИ ЖЕНЩИНАМИ И ЖЕНЩИНАМИ, ИМЕЮЩИМИ МАЛОЛЕТНИХ ДЕТЕЙ, ВО ВРЕМЕНА ГУЛАГА
}

\begin{abstract}
Аннотация: Предметом исследования являются политические, правовые, сочиально- экономические и криминологические аспекты отбывания наказания в виде лишения свободы беременными женщинами и женщинами, имеющими малолетних детей, в учреждениях ГУЛАГа. В частности, это политическая обстановка в данный исторический период, обусловившая режим репрессий в названных исправительных учреждениях; нормативноправовой статус исследуемой категории осужденных и положения детей, содержащихся совместно с осужденными матерями; статистика беременностей и родов, количества детей, находящихся в учреждениях ГУЛАГа; заболеваемости и смертности в них; анализ официальных архивных документов и комментариев реальных участников процесса исполнения наказания в названных учреждениях. Методология исследования построена на использовании автором как общенаучных (индукция, дедукция, и т.n.), так и частных методов и приемов научного анализа (ретроспективный, статистический, документальный, сравнительно- правовой и т.д.), а также изучении ранее использовавшихся нормативно- правовых актов, опубликованных официально интервью, иных первоисточников полученной информации. Статья представляет собой научное исследование проблемы отбывания наказания беременными женщинами и женщинами, имеющими малолетних детей, в учреждениях ГУЛАГа. Научная новизна очевидна, поскольку данная тема исследована в уголовно- исполнительном праве и криминологии крайне недостаточно. Правовая база данного института, а также статистика и материалы, касаюшиеся темы исследования, в свое время отличающиеся повышенной секретностью, представляют собой образец крайне сурового отношения власти и законодателя к положению и условиям отбывания лишения свободы исследуемой категорией женщин и их детей. Таким образом, авторский анализ данной проблемы -это новый оригинальный научный «срез» одной из трагических странии истории России в части пенитенщиарной и криминологической политики страны того времени.

Abstract: The object of studies includes political, legal, social, economic, and criminological aspects of serving punishment in the form of deprivation of freedom by the pregnant women and women with infants at the GULAG institutions. In particular, it includes the political situation at the relevant historic period, causing the regime of repressions in the said correctional institutions; normative legal status of the said category of convicts and their children, who were kept together with their mothers; statistical data for pregnancies and childbirth; number of children held in the GULAG institutions, rate of illnesses and death there; analysis of the official archive documents and commentaries of participants of the process of implementation of punishments in the said institutions. The methodology of studies was based on the use of general scientific methods (induction, deduction, etc.), and special legal methods and means of scientific analysis (retrospective and statistical analysis, documental, comparative legal analysis, etc.), as well as the studies of the previously used normative legal acts, officially published interviews, other primary sources for the information. The article contains a scientific study of the problem of serving punishment by the pregnant women and women with infants at the GULAG institutions. The scientific novelty of the work is obvious, since this topic is not sufficiently studied both in the spheres of criminology and penal law. The scientific basis for this institution, as well as statistics and materials regarding the topic of the studies were previously top secret, and they show the very strict attitude of the government towards the situation and conditions for serving prison term for the said categories of women and their children. Therefore, the analysis of this problem by the author is a new original scientific "snapshot" of one of the tragic pages of the Russian history in part of penitentiary and criminological policy of Russia of that time.
\end{abstract}

Ключевые слова: учреждения ГУЛАГа, осужденные беременные женщины, малолетние дети, правовой статус, статистика родов, заболеваемость, смертность детей, медицинская помощь, амнистии, исторический опыт. Keywords: GULAG institutions, convicts, pregnant women, infants, legal status, childbirth statistics, illness rate, death rate of children, medical aid, amnesty, historical experience. 


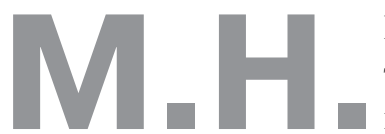

Гернет в своей работе «История царской тюрьмы» от-

метил, что положение заключенных женщин в царской России XIX века было тяжелым и фактически не отличалось от положения мужчин. Однако и с наступлением XX века положение женщин в местах лишения свободы не улучшилось. Особенной суровостью отличались условия отбывания наказания для беременных женщин и женщин, имеющих малолетних детей.

После 1917 года, практически все благотворительные организации, которые занимались попечительской деятельностью в местах заключения осужденных женщин, содержащихся с их детьми, были ликвидированы. Советская репрессивная система, главную и неотъемлемую часть которой составлял ГУЛАГ, служила исключительно интересам тоталитарного государства. Сталинские концентрационные лагеря, где в отдельные периоды удельный вес женщин среди осужденных доходил до $26 \%$, были местом жесточайшего произвола и насилия, бесправия и унижения человеческого достоинства, изощренных издевательств и каторжного труда. Женщина в этих условиях стала объектом беспощадной эксплуатации, как со стороны государства, так и со стороны лагерных служащих.

При этом, если в 1920-е гг. пенитенциарная система не входила в число запретных тем и обсуждалась в открытой печати с партийно-классовых позиций, то с августа 1930 г. был введен запрет на публикацию любых сведений о местах заключения, действовавший до середины 1950 -х гг. ${ }^{1}$

Справедливости ради, стоит отметить, что в законодательные акты того времени периодически вносились изменения, незначительно улучшающие положение женщин и их малолетних детей в местах лишения свободы.

Так, в Положении об общих местах заключения РСФСР (далее - Положение 1920 г.), утвержденном постановлением Народного комиссариата юстиции РСФСР от 15 ноября 1920 года, указано, что в местностях, где нет специальных женских мест заключения или отделений, заключенные женщины должны помещаться в камерах, изолированных от остальных. В отношении вопроса отбывания наказания женщинами, имеющими малолетних детей, в Положении было определено, что с заключенными женщинами могут приниматься только грудные дети, которые помещаются со-

${ }^{1}$ Иванова Г.М. История ГУЛАГа, 1918 - 1958: социально-эко-
номический и политико-правовой аспекты. М., 2006. С. 18 - 20. вместно с матерями. При этом особенности содержания их отдельным образом не регламентировались, также как и отсутствовали специальные нормы об улучшенном питании, прогулках, вещевом обеспечении, льготных условиях труда данной категории осужденных.

В соответствии с изменениями, внесенными в Исправительно-трудовой кодекс РСФСР 1924 года (далее - ИТК РСФСР 1924 г.), а затем и в Исправительнотрудовой кодекс РСФСР 1933 года (далее - ИТК РСФСР 1933 г.), правовое положение женщины, имеющей ребенка, существенно улучшилось.

Например, в ИТК РСФСР 1924 г. было впервые указано о привилегированном положении беременной женщины при «посылке на работу». Так, в соответствии со ст. 58 указанного правового акта заключенные женщины, начиная с пятого месяца беременности, не подлежат посылке на работы вне места заключения без их согласия. В отличии от Положения 1920 г., где говорилось только о возможности приема грудных детей и их содержании совместно с матерями, в ст. 109 ИТК РСФСР 1924 г. содержится прямое указание о приеме грудных детей в исправительно-трудовое учреждение при согласии на то заключенных женщин-матерей. В соответствии со ст. 114 ИТК РСФСР 1924 г. «заключенные женского пола и несовершеннолетние, а также правонарушители из рабоче-крестьянской молодежи в возрасте от 16 до 20 лет помещаются в специально для них предназначенные исправительно-трудовые учреждения». При этом, если в отношении несовершеннолетних в нормативной базе имелся раздел, разъясняющий правила содержания данной категории лиц в так называемых «трудовых домах», то, касательно женского пола, сведения о том какие исправительнотрудовые учреждения являются для них специально предназначенными отсутствовали. ${ }^{2}$

В Положении об исправительно-трудовых лагерях, утвержденном постановлением СНК СССР от 7 апреля 1930 года, содержалось разъяснение, которое уточняло возраст принимаемых детей. Так, в ст. 11 данного Положения указано: «Вместе с заключенными женщинами могут быть принимаемы в лагеря дети только в возрасте до 2 лет, которые помещаются с матерями». В примечании к указанной статье говорилось о том, что дети старше 2 лет могут быть оставлены при родителях впредь до передачи их лицам, которых родители укажут, или до помещения их в детский дом. Условия и порядок содержания женщин Положением не регламентировался. Между тем в п. 22 впервые содержалось

\footnotetext{
${ }^{2}$ Исправительно-трудовой кодекс РСФСР от 16.10.1924 г.
} 


\section{Право и политика 5 (173) • 2014}

упоминание о материально-бытовом обеспечении заключенных, в частности, что выдача одежды, обуви, белья и постельных принадлежностей осуществляется «по мере необходимости». ${ }^{3}$

В ИТК РСФСР 1933 г. были внесены законодательные нормы, расширяющие права рассматриваемой категории женщин. Согласно ст. 18: «Беременные и кормящие грудью женщины не могут направляться на исправительно-трудовые работы вне места их жительства. Они вовсе не могут привлекаться к работам до родов и после родов в сроки, указанные Кодексом законов о труде РСФСР, и пользуются всеми льготами, установленными этим кодексом для беременных и кормящих женщин». Женщины получили право содержания при себе детей в возрасте до четырех лет, для которых законодательно была установлена обязательная организация яслей. ${ }^{4}$

Несмотря на то, что в законодательстве правовое положение женщин последовательно улучшалось, объективная реальность, воссозданная на основе воспоминаний бывших узниц ГУЛАГа свидетельствует, что выжить в тех условиях можно было только чудом. Так, по воспоминаниям Хавы Волович, получившей 15 лет лагерей (не осведомленной даже впоследствии за что), беременные рожали детей в лагере. В случае рождения живого ребенка мать получала для новорожденного несколько метров портяночной ткани. Хотя новорожденный и не считался заключенным, ему выписывался отдельный детский паек. Кормящие матери получали 400 граммов хлеба, три раза в день суп из черной капусты или из отрубей, иногда с рыбьими головами. От работы женщин освобождали непосредственно перед родами. Днем матерей под конвоем провожали к детям для кормления. В некоторых лагерях матери оставались на ночь с детьми. ${ }^{5}$

Вот как описала жизнь новорожденных и маленьких детей ГУЛАГа Г.М. Иванова: «Нянями в бараке работали заключенные женщины, осужденные за бытовые преступления, имеющие своих детей. В семь часов утра няньки делали побудку малышам. Тычками, пинками поднимали их из ненагретых постелей (для «чистоты» детей одеяльцами их не укрывали, а набрасывали их поверх кроваток). Толкая детей в спинки кулаками и осыпая грубой бранью, меняли

\footnotetext{
${ }^{3}$ Постановление СНК ССР «Об утверждении положений об исправительно-трудовых лагерях» от 07.04.1930// РГАСПИ. Ф. 17. Оп. 162. Д. 11. Л. 57, 63. Подлинник.

${ }^{4}$ Исправительно-трудовой кодекс РСФСР от 01.08.1933 г.

${ }_{5}^{5}$ Волович Х. В. О прошлом // Озерлаг: как это было / сост. Л. С. Мухин. - Иркутск : Вост. - Сиб. кн. изд-во, 1992. - С. 55-87.
}

распашонки, подмывали ледяной водой. А малыши даже плакать не смели. Дети, которым полагалось уже сидеть или ползать, лежали на спинках, поджав ножки к животу, и издавали странные звуки, похожие на приглушенный голубиный стон». ${ }^{6}$

Об ужасающем состоянии данных мест заключения говорила высокая смертность осужденных. Так, в докладной записке Г.Г. Ягоды на имя Я.Э. Рудзутака от 26 октября 1931 года отмечалось: «Заболеваемость и смертность спецпереселенцев велика... Месячная смертность равна 1,3 процента к населению за месяц в Северном Казахстане и 0,8 процента в Норильском крае. В числе умерших особенно много детей младших групп. Так, в возрасте до 3-х лет умирает в месяц 8-12 процентов этой группы, а в Магнитогорске - еще больше, до 15 процентов в месяц... ... большая смертность зависит от жилищного и бытового неустройства и в связи с отсутствием необходимого питания»?

Порядок содержания осужденных женщин с детьми на протяжении данного периода времени неоднократно менялся. Если в соответствии со ст.46 УИК РСФСР 1933 г. женщины могли иметь при себе детей до четырех лет, то с 1954 г. Положением об исправительно-трудовых лагерях и колониях Министерства внутренних дел СССР от этот срок был ограничен двумя годами. ${ }^{8}$ Вместе с тем эти установленные законодательством нормы в действительности фактически не применялись. В 1936-1937 гг. пребывание детей в лагерях было признано фактором, понижающим дисциплину и производительность заключенных-женщин.

Далее, 1 апреля 1936 года ВЦИК и СНК СССР приняли Постановление «О порядке передачи детей на воспитание (патронаж) в семьи трудящихся», а 15 августа 1937 года издан оперативный приказ НКВД СССР № 00486 «Об операции по репрессированию жен и детей изменников родины». Согласно данному секретному документу, грудные дети направлялись вместе с их осужденными матерями в лагеря, откуда по достижении возраста 1-1,5 лет передавались в детские дома и ясли Наркомздравов республик. При

\footnotetext{
${ }^{6}$ ГУЛАГ: Его строители, обитатели и герои: (Раскулачивание и гонение на Православную Церковь пополняли лагеря ГУЛАГа) / Г.М.Иванова, Т.И.Славко, Г.Ф.Весновская, А.Н.Артемов, И.В. Добровольский; Под ред.: Добровольский И.В.; Отв. ред. Новицкий В.М. ;Междунар. О-во Прав Человека. - [2-е изд., расшир.]. - Франкфурт /М.; М. :Междунар. О-во Прав Человека (МОПЧ), 1999. - 453 с

${ }^{7}$ Тимофеев В.Г. Уголовно-исполнительная система России: цифры, факты и события/ Учебное пособие, Чувашский государственный университет им. И.Н. Ульянова, Чебоксары, 1999

${ }^{8}$ ГАРФ. Ф. 9401. Оп. 1а. Д. 527. Лл. 330-340. Типогр. экз.
} 
этом начальники органов НКВД решали вопрос об определении детей до 3-лет в детские дома и обеспечивали их немедленный и безотказный прием. Дети в возрасте от 3-х до 15 лет принимались на государственное обеспечение.

Согласно п. 29 данного документа при производстве ареста жен осужденных, дети у них изымались, и вместе с их личными документами (свидетельством о рождении, ученическими документами) в сопровождении «специально наряженных в состав группы, производящей арест, сотрудника или сотрудницы НКВД», отвозились в зависимости от возраста в детские дома и ясли, в приемно-распределительные пункты или в другие специально для них предназначенные помещения». ${ }^{9}$

Энн Эпплбаум в своей книге «Паутина Большого террора» пишет, что на практике беременных и матерей с грудными детьми арестовывали регулярно. Во время рутинного осмотра прибывшего в лагерь этапа один лагерный врач обнаружил женщину, у которой уже шли схватки. Ее арестовали на седьмом месяце беременности. Другую женщину, Наталию Запорожец, отправили в ссылку на восьмом месяце беременности. После езды в тряских вагонах и в кузове грузовика она родила мертвого ребенка. Художница и автор воспоминаний Ефросиния Керсновская помогала принимать ребенка, который родился в вагоне во время этапа. Детей старше грудного возраста тоже «арестовывали» вместе с родителями. В начале 1920-х годов одна заключенная написала из тюрьмы Дзержинскому едкое письмо, где «благодарила» его за арест ее трехлетнего сына: тюрьма, пишет она, гораздо лучше детского дома, который она называет «фабрикой ангелов» (то есть мертвых детей). ${ }^{10}$

Пожеланиям родственников взять на свое полное иждивение оставшихся сирот не препятствовали. При этом порядок их выдачи под опеку определялся другим секретным документом: 7 января 1938 г. был издан Циркуляр НКВД СССР «О выдаче на опеку родственникам детей репрессированных родителей». Помимо первичной проверки опекуна, сотрудникам НКВД предписывалось установить систематическую проверку за состоянием воспитания детей опекунами, настроениями детей, их поведением и знакомствами,

\footnotetext{
${ }^{9}$ Оперативный приказ НКВД СССР № 00486 «Об операции по репрессированию жен и детей изменников родины» от 15.08.1937// «Мемориал-аспект», № 2-3. Октябрь 1993 г.

10 Энн Эпплбаум. Паутина Большого террора. GULAG. A HISTORY. - М.: Московская школа политических исследований, 2006. С. 580-608.
}

а также тем влиянием, которое оказывают на детей лица, взявшие детей на опеку. ${ }^{11}$

По воспоминаниям бывшей узницы ГУЛАГа дети, достигшие годовалого возраста, отправлялись в принудительном порядке в детские дома, о чем делалась пометка в личном деле матери, однако без указания адреса. Принудительные отправки лагерных детей планировались и проводились как военные операции - чаще всего глубокой ночью, но редко удавалось избежать душераздирающих сцен, когда обезумевшие от ужаса разлучения с детьми матери бросались на надзирателей, на колючую проволоку заграждения.

По состоянию на 10 июля 1938 года, НКВД СССР направил в детские дома, находившиеся в ведении народных комиссариатов просвещения союзных республик, 17355 детей, оставшихся сиротами или без средств существования вследствие лишения свободы или расстрела их родителей.

По состоянию на 1 марта 1940 г. в ГУЛАГе функционировали 90 «домов младенцев», в которых воспитывались 4595 детей, матери которых отбывали лишение свободы. Один из примеров таких домов существовал на территории Норильлага: по состоянию на 1951 г. в «домах младенца» Норильлага находились 534 ребенка, а в течение года умерли 59 детей. В 1952 г. должны были появиться на свет 328 детей, и общая численность младенцев составила бы 803. Однако по документам 1952 г. числилось всего 650, что подтверждает высокую детскую смертность. ${ }^{12}$

Следует отметить, что положение «лагерных» детей и в детских домах было не лучшим: они были переполнены, грязны и недоукомплектованы персоналом. Детская смертность таже была высокой. По информации бывшей заключенной, все одиннадцать детей из лагеря, где она отбывала наказание, отправленные в спецдетдома Архангельска, умерли во время эпидемии. ${ }^{13}$

Начиная с 1933 года количество лагерных заключенных, в том числе и женщин, неуклонно росло.

Количество родившихся детей в местах заключения среди спецпереселенцев также ежегодно увеличивалось.

\footnotetext{
${ }^{11}$ Циркуляр НКВД СССР «О выдаче под опеку родственникам детей репрессированных родителей» от 07.01.1938// «Мемориаласпект», № 12. Ноябрь 1994 г.

${ }^{12}$ Норильский мемориал / Правление Норильской городской организации Всесоюзного историко-просветительского общества «Мемориал»; Ред. Львов А. - Норильск, 1998. № 4. С. 3.

13 Энн Эпплбаум. Паутина Большого террора. GULAG. A HISTORY. - М.: Московская школа политических исследований, 2006. C. $580-608$
} 


\begin{tabular}{|c|c|c|c|c|c|c|c|c|}
\hline Годы & $\mathbf{1 9 3 3}$ & $\mathbf{1 9 3 4}$ & $\mathbf{1 9 3 5}$ & $\mathbf{1 9 3 6}$ & $\mathbf{1 9 3 7}$ & $\mathbf{1 9 3 8}$ & $\mathbf{1 9 3 9}$ & $\mathbf{1 9 4 0}$ \\
\hline $\begin{array}{c}\text { Общее число } \\
\text { заключенных }\end{array}$ & 334.300 & 510.307 & 725.483 & 843.406 & 820.881 & 996.367 & 1.317 .195 & 1.344 .408 \\
\hline $\begin{array}{c}\text { Из них } \\
\text { женщин }\end{array}$ & $\begin{array}{c}\text { Данных } \\
\text { нет }\end{array}$ & $\begin{array}{c}30108 \\
\mathbf{( 5 , 9 \% )}\end{array}$ & $\begin{array}{c}44.980 \\
\mathbf{( 6 , 2 \% )}\end{array}$ & $\begin{array}{c}51.120 \\
\mathbf{( 6 , 1 \% )}\end{array}$ & $\begin{array}{c}50320 \\
\mathbf{( 9 , 1 \% )}\end{array}$ & $\begin{array}{c}68.749 \\
\mathbf{( 6 , 9 \% )}\end{array}$ & $\begin{array}{c}109.986 \\
\mathbf{( 8 , 4 \% )}\end{array}$ & $\begin{array}{c}108.898 \\
\mathbf{( 8 , 1 \% )}\end{array}$ \\
\hline $\begin{array}{c}\text { Число } \\
\text { родившихся } \\
\text { младенцев }\end{array}$ & 17082 & 14033 & 26122 & 27617 & 29036 & 31867 & 33716 & 32732 \\
\hline
\end{tabular}

Далее, история института отбывания лишения свободы осужденных матерей с детьми, свидетельствует о безобразном материально-бытовом и медицинском обеспечении заключенных в 1950-е гг. Документы Министерства внутренних дел, датированные 1952 и 1953 годами, проливают свет на положение женщин и детей в системе Главного управления лагерей железнодорожного строительства на закате сталинской эпохи. «Выписка из доклада комиссии на имя Министра внутренних дел товарища Круглова С. Н. от 4 декабря 1952 года за № 50/2257 с» указывала на то, что стоимость содержания заключенных в северных и дальневосточных лагерях ГУЛЖДС примерно вдвое дороже, чем их содержание в других лагерях. Исходя из этого, делался вывод о необходимости размещения, в частности, матерей с детьми в лагерях ГУЛАГа, расположенных в более благоприятных климатических условиях. По неизвестным причинам, заключение на это предложение было отрицательным. Следствием тяжелых бытовых условий только за 10 месяцев 1952 г. явились 1486 случаев первичных заболеваний на среднемесячное количество детей - 408 человек. Учитывая, что за этот же период умерло 33 ребенка (или 8,1 процента от общего количества), получается, что в среднем за этот период каждый ребенок переболел различными заболеваниями четыре раза. Среди причин смерти лидировали дизентерия и диспепсия $(45,5 \%)$, а также воспаление легких (30,2\%). Дети умирали в 16 раз чаще, чем взрослый контингент осужденных. Так, в Ягринском ИТЛ за 1947 год и 5 месяцев 1948 года умерло 33 ребенка, в том числе 7 - от токсической пневмонии, 10 - от дифтерии, 10 - от воспаления легких и 6 от прочих заболеваний. ${ }^{14}$

Представление о бытовом содержании женщин в ГУЛАГе дает секретная докладная записка комиссии ГУЛАГа Министерства юстиции от 27 июня 1953 г. начальнику ГУЛАГа И.И. Долгих, подготовленная по результатам проверки условий размещения и режима содержания заключенных, прибывающих в Кунеевский ИТЛ. В ней говорится о том, что «заключённые размещены в одноэтажных и двухэтажных бараках, за исключением двух женских лагерных пунктов 6 и 11 лагерных отделений, где заключённые женщины размещены в палатках, причём лагерный пункт одиннадцатого лагерного отделения предложено закрыть, т. к. помещения, где размещены заключённые женщины, не пригодны для жилья. Женский лагерный пункт 6 лагерного отделения не имеет коммунально-бытовых служб (столовой, бани, прачечной, кипятилки и др.).. В значительной части лагерных подразделений и объекта работ состояние водоснабжения неудовлетворительное».

Несмотря на то, что в исправительно-трудовых кодексах 1924 и 1933 гг. предписывалось раздельное содержание осужденных женщин и мужчин, Инструкция «О режиме содержания заключенных», объявленная приказом НКВД СССР № 008891939 года, разрешала совместное размещение заключенных в общих зонах, но в отдельных бараках.

А.И. Солженицын в своей книге «Архипелаг ГУЛаг» так описывает то время: «Вагонка, обвешанная

\footnotetext{
14 Женское лицо ГУЛАГа. Как на Мёртвой дороге росло население СССР. Вадим Гриценко, Вячеслав Калинин// Новая Газета от 08.04.2009
} 
от соседок тряпьем - классическая лагерная картина. Но есть и гораздо проще. Это опять-таки кривощековский 1-й лагпункт, 1947-1949... На лагпункте - блатные, бытовики, малолетки, инвалиды, женщины и мамки - всё перемешано. Женский барак всего один - но на пятьсот человек. Он - неописуемо грязен, несравнимо грязен, запущен, в нем тяжелый запах, вагонки - без постельных принадлежностей. Существовал официальный запрет мужчинам туда входить - но он не соблюдался и никем не проверялся». ${ }^{15}$

администрации, пользуясь покровительством Ершова, отбирали у заключенных посылки, заработную плату, склоняли женщин к сожительству - царил произвол. Все это привело к массовой распущенности среди заключенных-женщин...»

Таким образом, сожительство мужчин и женщин, в том числе и по принуждению, было весьма распространенным явлением в местах лишения свободы. Количество беременных и имеющих детей женщин возрастало.

Динамика беременностей и родов в лагерях ГУЛАГа (1947-1953 z2.)

\begin{tabular}{|l|l|l|l|l|l|l|l|}
\hline Годы & $\mathbf{1 9 4 7}$ & $\mathbf{1 9 4 8}$ & $\mathbf{1 9 4 9}$ & $\mathbf{1 9 5 0}$ & $\mathbf{1 9 5 1}$ & $\mathbf{1 9 5 2}$ & $\mathbf{1 9 5 3}$ \\
\hline Кол-во детей & 14630 & 10217 & 22815 & 19260 & 14713 & 28219 & 35505 \\
\hline $\begin{array}{l}\text { Кол-во } \\
\text { беременных }\end{array}$ & 6779 & 4588 & 9310 & 11950 & 6888 & 11096 & 6286 \\
\hline
\end{tabular}

В лагерях ГУЛАГа женщины нередко подвергались насилию - как физическому, так и психологическому. О данном факте свидетельствуют, например, приказ начальника Карлага: «Приставание к женщинам и понуждение их к сожительству со стороны лиц адмтехсостава... вызовы женщин на ночные работы, отбор «подходящих» женщин в качестве обслуги или домработницы, все эти безобразные факты продолжают иметь место в отделениях...» ${ }^{16}$

Некоторые штрихи положения женщин в лагерях «Строительства 501» представляет, например, «Протокол второй партконференции Обского ИТЛ Строительства 501 МВД СССР. 2 - 4 июня 1951 года, г. Салехард». В нем сообщается: «На 34-м женском лагпункте.. в течение длительного времени содержались 59 человек мужчин, из них: 21 человек, преимущественно осужденные за к/р преступления - измену Родине, использовались на низовой руководящей, административной работе. И лагпункт был в руках этих заключенных. Сам Ершов (начальник) в личных целях использовал заключенных женщин в качестве домработниц и вышивальщиц личных вещей. Заключенные из низовой

${ }^{15}$ А. Солженицьн. Архипелаг ГУЛАГ. М. Издательство: ИНКОМHB, 1991 г., с. 544

${ }^{16}$ Бастемиев С.К. Исправительные учреждения Казахстана (историко-правовой аспект). Монография. Павлодар, Кереку, 2009-258 с.
По состоянию на 1 января 1948 года в ИТЛ и ИТК содержалось 2356685 заключенных. При этом с 1 января 1948 года по 1 марта 1949 года число осужденных женщин с детьми возросло на 138\% и беременных женщин на 98\%. Женщины с детьми и беременные составляли $6,3 \%$ от общей численности заключенных женщин, содержащихся в лагерях и колониях. Содержавшиеся в местах заключения осужденные женщины с детьми и беременные размещались в 234 специально приспособленных помещениях, и реже - в отдельных секциях бараков. ${ }^{17}$

В докладной записке о положении заключенных женщин и роста количества беременных в лагерях и колониях МВД СССР говорится: «До войны и даже до 1947 года значительная масса женского контингента осуждалась на сравнительно короткие сроки заключения. Это являлось серьезным сдерживающим фактором для женщин к сожительству, так как они имели перспективу быстрее вернуться к своей семье и нормально устроить свою жизнь. Осужденные на длительные сроки такую перспективу в известной степени теряют и легче идут на нарушение режима и, в частности, на сожительство и беременность, рассчитывая благодаря этому на облегченное положение и даже на досрочное 17 Земсков В.Н. ГУЛАГ (историко-социологический аспект) // Соци-
ологические исследования. 1991. №.6. С. 10-27; 1991. №.7. С. 3 - 16 
DOI: $10.7256 / 1811-9018.2014 .5 .11289$

При цитировании этой статьи сноска на доі обязательна

\section{Право и политика $5(173) \cdot 2014$}

освобождение из заключения. Увеличение сроков осуждения большинства заключенных женщин безусловно влияет на рост беременности в лагерях и колониях». ${ }^{18}$

Несомненно, что немаловажным фактором было и улучшенное питание данной категории осужденных.

В данном случае стоит отметить, что в соответствии с приказом НКВД СССР № 00943 «О введении новых норм питания и вещевого довольствия для заключенных в ИТЛ и ИТК НКВД СССР» от 14 августа 1939 года (с грифом «сов.секретно») улучшенное питание для заключенных беременных женщин за 2 месяца до родов и в течение 9 месяцев после родов (период кормления ребенка грудью) в исправительно-трудовых лагерях и колониях НКВД СССР (на 1 человека в день в граммах) состояло из следующих продуктов:
При этом, в соответствии с примечаниями: к данной норме выдавался дополнительно один усиленный дополнительный паек (УПД) без 100 граммов хлеба. Молоко, творог, сметана и яйца выдавались за счет ресурсов собственных подсобных хозяйств лагеря-колонии или приобретались в порядке децентрализованных закупок. ${ }^{19}$

Одной из других причин роста числа беременных женщин было желание выйти на свободу по амнистии, что периодически практиковалось в отношении осужденных женщин с маленькими детьми. Такие амнистии (одну из них, например, объявили в 1945-м, другую в 1948 году) обычно не относились к женщинам, осужденным за контрреволюционные преступления.

По воспоминаниям Солженицына А.И., «Для мамок с грудными детьми выходили частные амнистии или

\begin{tabular}{|l|l|l|l|}
\hline \multicolumn{1}{|c|}{ Наименование продуктов } & \multicolumn{1}{|c|}{ Количество } & \multicolumn{1}{|c|}{ Наименование продуктов } & \multicolumn{1}{c|}{ Количество } \\
\hline Хлеб ржаной & 800 & Макароны & 17 \\
Мука пшеничная 85\% & 110 & Сахар & 33 \\
Мука подболточная 85\% & 10 & Чай суррогатный & 2 \\
Крупа разная (кроме диетич.) & 1 & Картофель и овощи & 700 \\
Мясо & 150 & Томат-пюре & 10 \\
Рыба & 60 & Перец стручковый & 0,13 \\
Растительное масло & 192 & Лавровый лист & 0,2 \\
Жиры животные & Соль & 20 \\
& 25 & Молоко & 400 \\
\hline
\end{tabular}

В соответствии с приказом МВД СССР № 0562 от 10 августа 1949г. суточная норма продовольственного снабжения детей в домах младенца лагерей и колоний МВД составляла:

\begin{tabular}{|l|l|l|l|}
\hline \multicolumn{1}{|c|}{ Наименование продуктов } & \multicolumn{1}{|c|}{ Количество } & \multicolumn{1}{|c|}{ Наименование продуктов } & \multicolumn{1}{|c|}{ Количество } \\
\hline Хлеб из муки простого помола & 150 & Кофе суррогатное & 1 \\
Хлеб из муки пшенич.сортовой & 150 & Картофель & 300 \\
Мука пшеничная 85\% помола & 40 & Овощи разные & 250 \\
Крупа диетическая & 30 & Мука картофельная & 5 \\
Макароны-вермишель & 10 & Фрукты сушеные & 15 \\
Мясо & 60 & Молоко свежее & 500 \\
Рыба & 100 & Творог & 20 \\
Жиры животные & Сметана & 20 \\
Сахар & Яйца (штук) & 0,75 \\
Соль & Мыло хозяйственное для всех & 400 \\
Чай натуральный & надобностей в месяц & \\
\hline
\end{tabular}

18 Докладная записка о состоянии изоляции заключенных женщин и наличии беременности в лагерях и колониях МВД СССР// ГАРФ.Ф. 9414 Д. 2549

\footnotetext{
19 Докладная записка о состоянии изоляции заключенных женщин и наличии беременности в лагерях и колониях МВД СССР// ГАРФ.Ф. 9414 Д. 2549
} 
просто распоряжения о досрочном освобождении. Чаще всего под эти распоряжения попадали мелкие уголовницы и приблатнённые, которые на эти-то льготы отчасти и рассчитывали. И как только такие мамки получали в ближайшем райцентре паспорт и железнодорожный билет, они своего ребенка, уже не ставшего нужным, частенько оставляли на вокзальной скамье, на первом крыльце. Так как не у всех было жильё, прописка, работа, средства для существования. Без ребенка было легче начинать жить». ${ }^{20}$

Руководители ГУЛАГа передавали некоторые сведения «наверх»: в докладной записке Сталину за 1949 год о положении женщин в лагерях неодобрительно отмечается, что из 503000 женщин, находящихся в данный момент в местах заключения, 9300 беременны и 23790 имеют при себе маленьких детей. «Учитывая крайне вредное влияние на здоровье и воспитание детей, оказываемое пребыванием в местах заключения», авторы записки предложили досрочно освободить беременных женщин и женщин с детьми до семи лет, находящимися либо в лагере при матери, либо дома без матери, - всего примерно 70000 женщин (но «политические», как и рецидивистки и осужденные за тяжкие преступления, освобождению не подлежали).

В целях исключения массового сожительства мужчин и женщин при исполнении уголовных наказаний Инструкция «О режиме содержания заключенных в исправительно-трудовых лагерях и колониях», объявленная приказом МВД СССР № 01901947 года, установила раздельное содержание мужчин и женщин в отдельных лагерных подразделениях и колониях. Этой инструкцией предусматривалось создание специальных женских подразделений и только в исключительных случаях разрешалось размещать женщин в мужских подразделениях, но в отдельных изолированных зонах. Выполнение ее требований затянулось на годы. По состоянию на 1 января 1950 года в системе исправительно-трудовых лагерей и колоний было организовано лишь 545 отдельных женских подразделений, в которых содержались $67 \%$ женщин от общей их численности в местах заключения, остальные $33 \%$ женщин содержались в общих с мужчинами подразделениях, но в отдельных выгороженных зонах..$^{21}$

По воспоминаниям Солженицына А.И., на Архипелаге в 1946 году началось и в 1948 закончилось

\footnotetext{
${ }^{20}$ Солженииьын А. Указ.соч., с. 284.

${ }^{21}$ Уголовно-исполнительная система 130 лет / М. Г. Детков, С. Х. Шамсунов, П. В. Ященко, В. И. Селиверстов. М. : Юриспруденция, 2009. $-304 \mathrm{c}$
}

отделение женщин от мужчин. Но эта мера имела последствия неожиданные и даже противоположные поставленной цели. С отделением женщин резко ухудшилось их общее положение в производстве. «Раньше многие женщины работали прачками, санитарками, поварихами, кубовщицами, каптерщицами, счетоводами на смешанных лагпунктах, теперь все эти места они должны были освободить, в женских же лагпунктах таких мест было гораздо меньше. И женщин погнали на «общие», погнали в цельно-женских бригадах, где им особенно тяжело. Вырваться с «общих» хотя бы на время стало спасением жизни. И женщины стали гоняться за беременностью, стали ловить её от любой мимолетной встречи, любого касания. И вот число детей, поступающих в дом малютки, за год возросло [вдвое!], хотя заключённых женщин за это время не прибавилось».22

В Ягринском ИТЛ в соответствии с приказом № 0190 женщин после 27 марта 1947 года стали сосредотачивать в отдельном лагерном пункте (ОЛП-3), входящем в состав Ягринлага. Но и год спустя 470 женщин все еще содержались в общих зонах, в 1949 году в общих с мужчинами зонах находилось 577 женщин. Женщин выводили на работу в основном на жилищное строительство и эллинг, использовали на земляных и вспомогательных работах, а также штукатурами, малярами, каменщиками, стекольщиками и на уборке мусора. Беременные женщины за три месяца до родов переводились на легкие работы, за 35 дней до родов - освобождались от работы. В декабре 1948 года было 25 беременных и 40 кормящих «мамок». В зоне третьего (женского) отделения был дом младенца, где содержались от 50 до 180 рожденных в неволе детей. На 28 сентября 1949 года Дом младенца обслуживали: медсестра, 13 нянь, завхоз, повар, посудомойка, две уборщицы и прачка.

28 августа 1950 года Указом Президиума Верховного Совета СССР предписывалось освобождение от наказания осужденных беременных женщин и женщин, имеющих малолетних детей. Справка, подписанная заместителем начальника 2-го управления ГУЛАГа МВД СССР полковником Никулочкиным, сообщала, что на 24 апреля 1951 года во исполнение этого указа из мест заключения были освобождены 100\% беременных женщин и женщин, имеющих при себе детей в местах заключения, а также 94,5\% женщин, имеющих детей вне лагеря-колонии. Всего было освобождено 119041 женщина из 122 738, попадающих в перечисленные категории.

\footnotetext{
${ }^{22}$ Солжениицын А. Указ.соч., с. 310
} 


\section{Право и политика $5(173) \cdot 2014$}

26 марта 1953 года Лаврентий Берия направил в президиум ЦК на имя т. Маленкова Г.М. объемную записку № ЛБ-25 с грифом «совершенно секретно», в которой приводил аргументы в пользу масштабной амнистии, назначенной на следующий день, - чтобы избавить лагеря от «лишних ртов», Берия предложил амнистировать как минимум миллион человек, а именно: всех осужденных на срок до 5 лет; всех беременных женщин, а также женщин, имеющих детей до 10 лет, всех несовершеннолетних, пожилых мужчин и женщин, а равно как и больных, страдающих тяжелым неизлечимым недугом. В докладной записке указывается: «Среди заключенных отбывают наказание 438788 женщин, из них 6286 беременных и 35505 женщин, имеющих при себе детей в возрасте до 2 лет. Многие женщины имеют детей в возрасте до 10 лет, оставшихся на воспитании у родственников или в детских домах... Известно, что заключение в лагерь, связанное с отрывом на продолжительное время от семьи, от привычных бытовых условий и занятий, ставит осужденных, их родственников и близких людей в очень тяжёлое положение, часто разрушает семью, крайне отрицательно сказывается на всей их последующей жизни. Большинство из этих заключённых хорошо ведёт себя в лагерях, добросовестно относится к труду и может вернуться к честной трудовой жизни. Учитывая изложенное, предлагается принять указ Президиума Верховного Совета СССР об амнистии..». ${ }^{23}$ Амнистия дала свободу почти половине всех заключенных - 1,2 миллиона человек из 2,5 миллиона лагерников, в том числе и женщинам, имеющим при себе детей в возрасте до двух лет. Однако большинства политических заключенных она не затронула. Вспыхнули волнения.

Было очевидно, что ГУЛАГ закончил свое существование. 1 сентября 1953 года секретным указом Президиума Верховного совета СССР было упразднено Особое совещание при НКВД СССР. По состоянию на 1 апреля 1954 года в числе заключенных ГУЛАГа содержались 1.182 .759 мужчин (87\%) и 177.544 женщины (13\%).

«Разгрузка» ГУЛАГа продолжалась путем целого ряда частичных амнистий. Так, в соответствии с Указом Президиума Верховного Совета СССР от 3 сентября 1955 года «О досрочном освобождении из мест лишения

23 Лаврентий Берия. 1953. Стенограмма июльского пленума ЦК КПСС и другие документы. Под ред. акад. А.Н. Яковлева; сост. В. Наумов, Ю. Сигачев. М., МФД. 1999. С. 19-21, со ссылкой на АПРФ. Ф. 3. Оп. 52. Д. 100. Л. 79. Подлинник. Опубликовано: «Исторический архив», 1996, № 4. свободы инвалидов, престарелых, лиц, страдающих тяжелым неизлечимым недугом, беременных женщин и женщин, имеющих малолетних детей» были амнистированы 77 тысяч 333 заключенных. За несколько лет (1953-1956) число отбывающих наказание в ГУЛАГе сократилось на две трети.

Начало 50-х гг. ознаменовало период некоторой либерализации в развитии пенитенциарной системы страны.

10 июля 1954 года распоряжением № 7688-рс утверждено Положение об исправительно-трудовых лагерях и колониях Министерства внутренних дел СССР (далее - Положение). В данном Положении устанавливалось, что осужденным женщинам, имеющим детей в возрасте до 2 лет, разрешается помещать их в дома младенца при исправительно-трудовых лагерях и колониях, где они содержатся за счет государства. При этом обращалось внимание на введение улучшенных жилищно- бытовых условий для беременных женщин, а также уточнялось, что кормящие матери из числа заключенных женщин размещаются в подразделении, находящемся в непосредственной близости от дома младенца.

Можно сказать, что с 1954 года начинается отсчет периода восстановления демократических начал и реформы исправительно-трудового права, что имело самое непосредственное отношение к развитию института отбывания лишения свободы женщинами - беременными и имеющими малолетних детей.

\section{Библиография:}

1. Бастемиев С.К. Исправительные учреждения Казахстана (историко-правовой аспект). Монография. Павлодар, Кереку, 2009-258 с.

2. Верт Н. Террор и беспорядок. Сталинизм как система. М.: Российская политическая энциклопедия РОССПЭН. 2010. 448 c.

3. Гернет М.Н. История царской тюрьмы. М., 1863. C. 396-397.

4. ГУЛАГ: Его строители, обитатели и герои: (Раскулачивание и гонение на Православную Церковь пополняли лагеря ГУЛАГа) / Г.М.Иванова, Т.И.Славко, Г.Ф.Весновская, А.Н.Артемов, И.В. Добровольский; Под ред.: Добровольский И.В.; Отв. ред. Новицкий В.М.; Междунар. О-во Прав Человека. - [2-е изд., расшир.]. - Франкфурт /М.; М.: Междунар. О-во Прав Человека (МОПЧ), 1999. - 453 с 
5. Иванова Г.М. История ГУЛАГа, 1918 - 1958: социально-экономический и политико-правовой аспекты. М., 2006. С. 18 - 20.

6. История советской политической цензуры: док. икоммент. М., 1997. С. $284-286$

7. Керсновская Е. Сколько стоит человек. М., 1996. T.3. C. $60-61$.

8. Тимофеев В.Г. Уголовно-исполнительная система России: цифры, факты и события/ Учебное пособие, Чувашский государственный университет им. И.Н. Ульянова, Чебоксары, 1999

9. Уголовно-исполнительная система 130 лет / М. Г. Детков, С. Х. Шамсунов, П. В. Ященко, В. И. Селиверстов. - М. : Юриспруденция, 2009. $-304 \mathrm{c}$

10. Энн Эпплбаум. Паутина Большого террора. GULAG. A HISTORY. - М.: Московская школа политических исследований, 2006. С. 580-608.

11. Нагорная О.С.. Восточногерманские студенты в СССР 1950-60-х гг.: транснациональные пространства и социалистические «сети» // Исторический журнал: научные исследования. - 2013. - № 5. C. 104-107. DOI: $10.7256 / 2222-1972.2013 .5 .9267$.

12. Н.В. Тищенко. Свобода и несвобода в пространстве литературных текстов: дискурс-анализ произведений, посвященных ГУЛАГу // Философия и культура. - 2013. - № 4. - С. 104-107. DOI: 10.7256/19992793.2013.04.8.

13. Шадрин А.Ю.. Кризис мобилизационной модели развития и распад СССР (1945 - 1991 гг.) // Политика и Общество. - 2013. - № 8. - С. 104-107. DOI: $10.7256 / 1812-8696.2013 .8 .7754$.

14. А. И. Головлев. Неравносторонний треугольник?: Кемалистская Турция, фашистская Италия и сталинский СССР в призме сравнительного анализа Plaggenborg St. Ordnung und Gewalt: Kemalismus - Faschismus - Sozialismus. München: Oldenbourg Verlag, 2012 // Исторический журнал: научные исследования. - 2013. - № 4. - С. 104-107. DOI: 10.7256/2222-1972.2013.4.8884.

15. А. С. Степанов. О коррупции в авиационной промышленности СССР в 1930-х - начале 1940-х годов // Исторический журнал: научные исследования. - 2013. - № 4. - C. 104-107. DOI: 10.7256/22221972.2013.4.7715.

16. Кононков П.Ф.. Обеспечение продовольственной безопасности СССР во время Великой Отечественной войны // Национальная безопасность / nota bene. - 2013. - № 3. - C. 104-107. DOI: $10.7256 / 2073-8560.2013 .3 .5276$.
17. А. Н. Паршин. Формирование и развитие механизма правового регулирования между СССР и Германией в сфере военного сотрудничества с 1922 по 1933 годы // Международное право и международные организации / International Law and International Organizations. - 2012. - № 2. - C. 104-107.

18. Ф. М. Гадаборщева. Реабилитация народов, подвергшихся депортации в середине XX века в СССР: (историко-правовые проблемы) // Политика и Общество. - 2011. - № 5.

19. А. И. Абатуров. Международные стандарты в области контроля над лицами, освобождёнными из мест лишения свободы // Международное право и международные организации / International Law and International Organizations. - 2012. - № 2. - C. 104-107.

20. О.Ю. Ельчанинова, А.П. Ельчанинов. Тюремные учреждения России в конце XIX-начале XX вв.: организационно-правовые основы, система управления, условия содержания осужденных (на материалах работ дореволюционных ученых) // Политика и Общество. - 2011. № 9. - C. 104-107.

21. Е. В. Клиньшанс. Гражданский контроль над системой исполнения наказаний в условиях модернизации органов государственной власти: зарубежный опыт // Политика и Общество. - 2011. - № 6. - C. 104-107.

22. Никулин В.В. Потребность в безопасности. Правовой статус ВЧК - ГПУ - ОГПУ в структуре советского государства // NB: Исторические исследования. -2013. - 6. - С. 25 -84. DOI: 10.7256/2306420X.2013.6.751. URL: http://www.e-notabene.ru/hr/ article $751 . \mathrm{html}$

23. Безгин В.Б. Инфантицид и криминальный аборт в сельской России: прошлое и современность // NB: Вопросы права и политики. - 2013. - 4. - С. 196 229. DOI: $10.7256 / 2305-9699.2013 .4 .653$. URL: http:// www.e-notabene.ru/lr/article_653.html

24. Васильев А.М. Смертная казнь в России: высшая, исключительная мера наказания, устрашение или политика? // NB: Вопросы права и политики. - 2013. -4. - C. 159-195. DOI: 10.7256/2305-9699.2013.4.674. URL: http://www.e-notabene.ru/lr/article_674.html

25. Тищенко Н.В. ГУЛАГ и дискурсивные практики: «крутой маршрут» русских писателей в советских лагерях // NB: Философские исследования. - 2012. - 3. - C. 1 - 43. URL: http://www.e-notabene.ru/fr/ article_173.html 


\section{Право и политика 5 (173) • 2014}

\section{References (transliteration):}

1. Bastemiev S.K. Ispravitel'nye uchrezhdeniya Kazakhstana (istoriko-pravovoi aspekt). Monografiya. Pavlodar, Kereku, 2009-258 s.

2. Vert N. Terror i besporyadok. Stalinizm kak sistema. M.: Rossiiskaya politicheskaya entsiklopediya ROSSPEN. 2010. 448 s.

3. Gernet M.N. Istoriya tsarskoi tyur'my. M., 1863. C. 396-397.

4. Ivanova G.M. Istoriya GULAGa, 1918 - 1958: sotsial'no-ekonomicheskii i politiko-pravovoi aspekty. M., 2006. S. $18-20$.

5. Kersnovskaya E. Skol'ko stoit chelovek. M., 1996. T.3. S. 60-61.

6. Timofeev V.G. Ugolovno-ispolnitel'naya sistema Rossii: tsifry, fakty i sobytiya/ Uchebnoe posobie, Chuvashskii gosudarstvennyi universitet im. I.N. Ul'yanova, Cheboksary, 1999

7. Enn Epplbaum. Pautina Bol'shogo terrora. GULAG. A HISTORY. - M.: Moskovskaya shkola politicheskikh issledovanii, 2006. S. 580-608.

8. Nagornaya O.S.. Vostochnogermanskie studenty v SSSR 1950-60-kh gg.: transnatsional'nye prostranstva i sotsialisticheskie «seti» // Istoricheskii zhurnal: nauchnye issledovaniya. - 2013. - № 5. - S. 104-107. DOI: 10.7256/2222-1972.2013.5.9267.

9. N.V. Tishchenko. Svoboda i nesvoboda v prostranstve literaturnykh tekstov: diskurs-analiz proizvedenii, posvyashchennykh GULAGu // Filosofiya i kul'tura. - 2013. - № 4. - S. 104-107. DOI: 10.7256/19992793.2013.04.8.

10. Shadrin A.Yu.. Krizis mobilizatsionnoi modeli razvitiya i raspad SSSR (1945 - 1991 gg.) // Politika i Obshchestvo. - 2013. - № 8. - S. 104-107. DOI: 10.7256/1812-8696.2013.8.7754.

11. A. I. Golovlev. Neravnostoronnii treugol'nik?: Kemalistskaya Turtsiya, fashistskaya Italiya i stalinskii SSSR v prizme sravnitel'nogo analiza Plaggenborg St. Ordnung und Gewalt: Kemalismus - Faschismus - Sozialismus. München: Oldenbourg Verlag, 2012 // Istoricheskii zhurnal: nauchnye issledovaniya. - 2013. - № 4. - S. 104-107. DOI: 10.7256/22221972.2013.4.8884.

12. A. S. Stepanov. O korruptsii v aviatsionnoi promyshlennosti SSSR v 1930-kh - nachale 1940-kh godov // Istoricheskii zhurnal: nauchnye issledovaniya. - 2013. - № 4. - S. 104-107. DOI: 10.7256/22221972.2013.4.7715.
13. Kononkov P.F.. Obespechenie prodovol'stvennoi bezopasnosti SSSR vo vremya Velikoi Otechestvennoi voiny // Natsional'naya bezopasnost' / nota bene. - 2013. - № 3 . - S. 104-107. DOI: 10.7256/2073-8560.2013.3.5276.

14. A. N. Parshin. Formirovanie i razvitie mekhanizma pravovogo regulirovaniya mezhdu SSSR i Germaniei v sfere voennogo sotrudnichestva s 1922 po 1933 gody // Mezhdunarodnoe pravo i mezhdunarodnye organizatsii / International Law and International Organizations. 2012. - № 2. - S. 104-107.

15. F. M. Gadaborshcheva. Reabilitatsiya narodov, podvergshikhsya deportatsii v seredine XX veka v SSSR: (istoriko-pravovye problemy) // Politika i Obshchestvo. -2011 . - № 5 .

16. A. I. Abaturov. Mezhdunarodnye standarty v oblasti kontrolya nad litsami, osvobozhdennymi iz mest lisheniya svobody // Mezhdunarodnoe pravo i mezhdunarodnye organizatsii / International Law and International Organizations. - 2012. - № 2. - S. 104-107.

17. O.Yu. El'chaninova, A.P. El'chaninov. Tyuremnye uchrezhdeniya Rossii v kontse XIX-nachale XX vv.: orga nizatsionno-pravovye osnovy, sistema upravleniya, usloviya soderzhaniya osuzhdennykh (na materialakh rabot dorevolyutsionnykh uchenykh) // Politika i Obshchestvo. - 2011. - № 9. - S. 104-107.

18. E. V. Klin'shans. Grazhdanskii kontrol' nad sistemoi ispolneniya nakazanii $\mathrm{v}$ usloviyakh modernizatsii organov gosudarstvennoi vlasti: zarubezhnyi opyt // Politika i Obshchestvo. - 2011. - № 6. - S. 104-107.

19. Nikulin V.V. Potrebnost' v bezopasnosti. Pravovoi status VChK - GPU - OGPU v strukture sovetskogo gosudarstva // NB: Istoricheskie issledovaniya. - 2013. -6. - C. 25 - 84. DOI: 10.7256/2306-420X.2013.6.751. URL: http://www.e-notabene.ru/hr/article_751.html

20. Bezgin V.B. Infantitsid i kriminal'nyi abort v sel'skoi Rossii: proshloe i sovremennost' // NB: Voprosy prava i politiki. - 2013. - 4. - C. 196 - 229. DOI: 10.7256/23059699.2013.4.653. URL: http://www.e-notabene.ru/lr/ article_653.html

21. Vasil'ev A.M. Smertnaya kazn' v Rossii: vysshaya, isklyuchitel'naya mera nakazaniya, ustrashenie ili politika? // NB: Voprosy prava i politiki. - 2013. - 4. C. 159 - 195. DOI: 10.7256/2305-9699.2013.4.674. URL: http://www.e-notabene.ru/lr/article_674.html

22. Tishchenko N.V. GULAG i diskursivnye praktiki: «krutoi marshrut» russkikh pisatelei v sovetskikh lageryakh // NB: Filosofskie issledovaniya. - 2012. - 3. - C. 1 - 43. URL: http://www.e-notabene.ru/fr/ article_173.html 